\title{
Richness and activity of arthropodophagous bats in an arid landscape of central México
}

\author{
María Cristina MacSwiney González ${ }^{1 *}$, Rafael Ávila-Flores², and Juan Manuel Pech Canché3 \\ ${ }^{1}$ Centro de Investigaciones Tropicales, Universidad Veracruzana. José María Morelos y Pavón 44 y 46, Centro, 91000, Xalapa. \\ Veracruz, México. Email: cmacswiney@uv.mx (MCMG). \\ ${ }^{2}$ División Académica de Ciencias Biológicas, Universidad Juárez Autónoma de Tabasco. Carretera Villahermosa- Cárdenas Km 0.5 \\ S/N, Entronque a Bosques de Saloya, 86150. Villahermosa. Tabasco, México. Email: rafaelavilaf@yahoo.com.mx (RAF). \\ ${ }^{3}$ Laboratorio de Vertebrados Terrestres, Facultad de Ciencias Biológicas y Agropecuarias, Universidad Veracruzana. Km. 7.5 \\ Carretera Tuxpan-Tampico, 92850, Tuxpan. Veracruz, México. Email: jmpech@gmail.com (JMPC). \\ *Corresponding author
}

The insectivorous bats of arid and semi-arid ecosystems have been poorly studied in México. The aim of this work was to determine the richness and activity of insectivorous bats in arid landscapes of central México over an annual cycle and identify the landscape and environmental features related to relative abundance patterns of bats. We carried out captures with mist nets and active acoustic monitoring in 10 transects, semi-active monitoring in eight stations, and passive monitoring in two desert grassland and scrub sites in Aguascalientes and Jalisco, from January to December 2012. The activity index of each insectivorous species was calculated and related to the local features at the landscape level. An automated monitoring weather station was established in the study area to explore the potential effect of environmental conditions on activity through time. Two species of insectivorous bats were captured: Myotis melanorhinus and M. occultus; seven additional species belonging to three families were acoustically identified, with Tadarida brasiliensis as the most active species. Activity levels were concentrated during the spring (April-June) and from mid-summer to late fall (August-October). The null activity in winter (January-March) and the increased activity of $T$. brasiliensis in the spring suggest migratory movements of the species in the region. The highest values of the activity index were recorded in the proximity of water bodies and ravines. Overall activity was recorded at temperatures between 6.8 and $20.3{ }^{\circ} \mathrm{C}$, and under wind speeds between 1.6 and $24.1 \mathrm{~km} / \mathrm{h}$.

Los murciélagos insectívoros de ecosistemas áridos y semiáridos han sido poco estudiados en México. El presente trabajo tuvo como objetivo el determinar la riqueza y actividad de murciélagos insectívoros en un paisaje desértico del centro de México a lo largo de un ciclo anual, así como identificar los elementos del paisaje y factores físicos que están relacionados con los patrones de abundancia relativa de los murciélagos. Se realizaron capturas con redes de niebla y monitoreo acústico activo en 10 transectos, semiactivo en ocho estaciones y pasivo en dos sitios de pastizal y matorral desértico de Aguascalientes y Jalisco, de enero a diciembre de 2012. Se estimó el índice de actividad de cada especie y se relacionó con las características locales del paisaje. Se estableció una estación de monitoreo automatizado en la zona de estudio para identificar si existían condiciones ambientales que afectaran la actividad de forma temporal. Se capturaron dos especies de murciélagos insectívoros, Myotis melanorhinus y M. occultus, y se identificaron acústicamente siete especies, pertenecientes a tres familias, siendo Tadarida brasiliensis la especie con mayor actividad. Los niveles de actividad se concentraron en dos temporadas, una en primavera y otra de mediados del verano hasta finales del otoño. La nula actividad en invierno e incremento de la actividad en primavera de T. brasiliensis podría indicar movimientos migratorios de la especie en la región. Los mayores valores del índice de actividad se registraron en los cuerpos de agua y cañadas. La actividad de murciélagos se registró en temperaturas entre los $6.8^{\circ} \mathrm{C}$ y $20.3^{\circ} \mathrm{C}$ y con velocidades de viento entre 1.6 y $24.1 \mathrm{~km} / \mathrm{h}$.

Keywords: activity index; aerial insectivores; landscape features; local features; migratory movements; ultrasonic detector.

(C) 2020 Asociación Mexicana de Mastozoología, www.mastozoologiamexicana.org

\section{Introduction}

The arid and semi-arid ecosystems of México are composed primarily of desert shrubland and grasslands that make about $30 \%$ of the remaining plant cover of the country (Comisión para el Conocimiento y Uso de la Biodiversidad 2019). These ecosystems are characterized by shrubs less than four meters high, with columnar cacti and agave as dominant species. These are also characterized by scarce rains that make them vulnerable to desertification, particularly facing the climate change scenario (Challenger and Soberón 2008). In these environments, the structure of plant communities changes significantly at small spatial scales, translating into highly heterogeneous landscapes that provide various resources for many species of mammals (Stapp 2010). As a result, the diversity of mammal assemblages in these ecosystems can be substantial (i. e. Elizalde-Arellano et al. 2014), including a high richness of insectivorous bats (i. e. Rojas-Martínez and Valiente-Banuet 1996).

Studies at the metacommunity level have found that the species within Vespertilionidae, Molossidae, and Phyllostomidae are dominant in arid environments of México (López-González et al. 2012). Despite the fact that insectivorous bats are the main guild in arid and semi-arid habitats in México, most studies on bats in these habitats have focused on documenting the interactions of nectarivores and frugivores with various species of agave and cactus plants (e. g. Silva-Montellano and Eguiarte 2003; Herrera and López 2017; Fleming and Holland 2018). In contrast, the patterns of diversity, behavior, and habitat use of insectivorous species are poorly known. 
The use of ultrasonic detectors combined with net sampling has proved to be a valuable tool to determine the richness of insectivorous species, not only in tropical environments (MacSwiney et al. 2008) but also in arid and semiarid ecosystems (López-González et al. 2015). In addition, these devices have made it possible to determine the elements of the landscape or local elements, such as bodies of water, that are key to promoting a higher diversity and as foraging sites in arid environments in northern México (López-González et al. 2016). In the present work, we used a combination of sampling techniques to describe the richness and activity patterns of insectivorous bats in a desert landscape of central México over an annual cycle, identifying those environmental factors and landscape elements that are related to the patterns observed.

\section{Materials and Methods}

Study area. The study area is located in the physiographic region known as Mesa del Centro, located between the Sierra Madre Occidental, the Sierra Madre Oriental, and the Trans-Mexican Volcanic Belt. The physiographic subprovince where the environmental system is located is called Llanuras de Ojuelos-Aguascalientes. The local climate temperate semi-arid (BS1 kw), with a mean annual temperature between 12 and $18^{\circ} \mathrm{C}$ and mean annual precipitation of 0.8 to $2.9 \mathrm{~mm}$ (García 2004). Two sampling sites were selected in the study area, located at opposite ends of an extensive plain. The first site belongs to the Ejido Palo Alto, in the municipality of Palo Alto, Aguascalientes ( $21^{\circ} 56^{\prime} 4.4^{\prime \prime}$ $\mathrm{N},-101^{\circ} 51^{\prime} 49.1^{\prime \prime} \mathrm{W}$ with a mean altitude of 2,397 masl, hereafter referred to as "ejido"). The second is a private ranch called "Las Chinampas", located in the municipality of Ojuelos de Jalisco, Jalisco ( $21^{\circ} 53^{\prime} 6.9^{\prime \prime} \mathrm{N},-101^{\circ} 50^{\prime} 49.2^{\prime \prime}$ W, 2,446 masl, hereafter referred to as "ranch"). The sites were separated by approximately $3.5 \mathrm{~km}$ (Figure 1). The study area is dominated by a mosaic of microphyll desert shrubland, rosetophilous desert shrubland, crasicaule shrubland, oak forest, eucalyptus forest, and natural grassland (Rzedowski 2006), with yucca trees (Yucca sp.) and cacti species of the genera Coryphanta and Opuntia. The vegetation cover tends to be more open in higher areas of the plain, while trees predominate in hillsides and ravines. The study sites include three artificial water reservoirs (presones) that were built by local ranchers to supply water for cattle, and a natural stream with small ponds.

Monitoring with mist nets. In each site, five mist nets were placed during four nights per month to capture bats along streams, slopes, and bodies of water (Figure 1), consider-
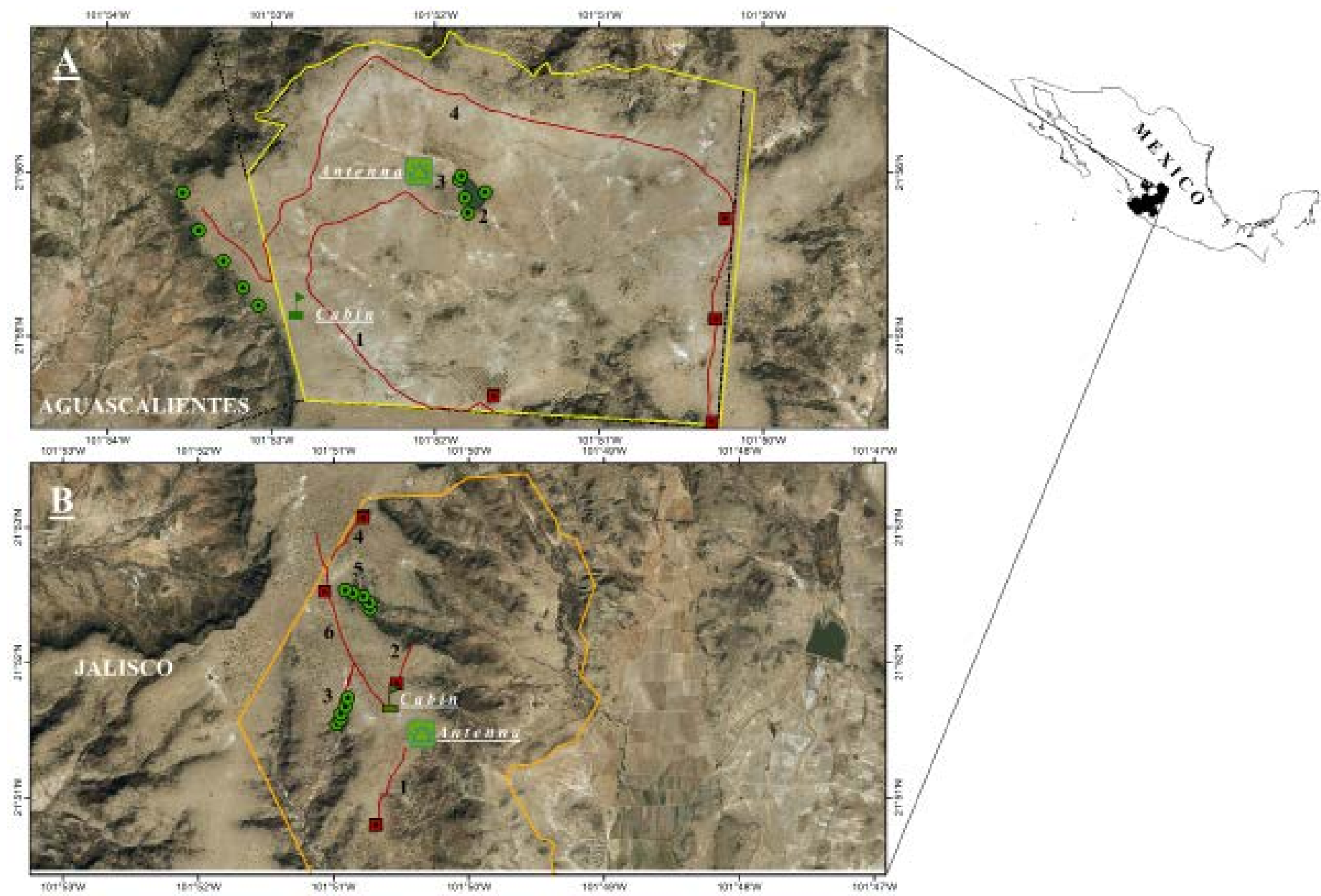

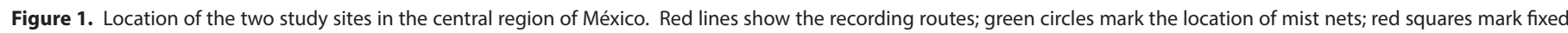

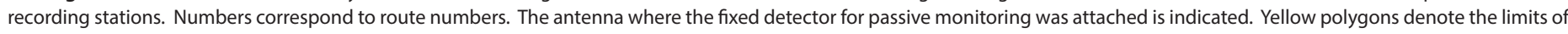

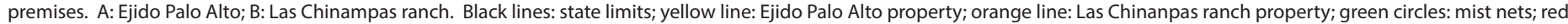
squares: ccoustic monitoring points; red line: routes 
ing that these areas may be used as feeding sites or flight routes for many species on their way to or from the plain. Nylon nets were $12 \mathrm{~m}$ long, with $38 \mathrm{~mm}$ mesh size (Avinet Research Supplies, United States), and were placed considering a minimum separation of $50 \mathrm{~m}$. These nets were kept open during five hours (starting at dusk) and were reviewed at 30-minute intervals. The individuals captured were photographed, weighed, measured, and identified to species according to the criteria described in Medellín et al. (2008). The sex and reproductive condition of each individual captured were determined. The individuals captured were released in an open space to record their vocalizations. These recordings were used to supplement our reference acoustic library and identify the pulses stored by ultrasonic detectors. Finally, we searched for bat shelters in crevices and cracks of slopes and ravines, as well as among the vegetation of plains (especially among dry yucca leaves), but did not spot any shelter near the study sites.

Acoustic monitoring. To maximize the spatial and temporal coverage of the sampling, we used hand-held detectors to conduct active and semi-active monitoring, as well as fixed detectors for passive monitoring. The routes of movements (active monitoring) for acoustic sampling were selected seeking to cover the maximum surface area sampled in each site; the only limitation was the use of the existing dirt roads only, aiming to include both plain and ravine areas that harbor oak forest, grasslands with oak trees and

Table 1. Description of the routes set for the monitoring of bats in the study area. The route length is indicated in parenthesis. Rout Number (RN).

\begin{tabular}{|c|c|c|c|}
\hline Study premises & RN & Vegetation types & Observations \\
\hline \multirow[t]{4}{*}{ Ejido Palo Alto } & 1 & $\begin{array}{l}\text { Predominantly grassland with } \\
\text { isolated shrubs; crosses a small } \\
\text { eucalyptus forest }\end{array}$ & On the plain $(4.7 \mathrm{Km})$ \\
\hline & 2 & $\begin{array}{l}\text { Dense and low shrubland, } \\
\text { dominated by thorny bushes; } \\
\text { some areas with bare soil }\end{array}$ & $\begin{array}{l}\text { On the plain; borders } \\
\text { part of the largest } \\
\text { reservoir }(0.33 \mathrm{Km})\end{array}$ \\
\hline & 3 & $\begin{array}{l}\text { Dense and low shrubland, } \\
\text { dominated by thorny bushes; } \\
\text { some areas with bare soil }\end{array}$ & $\begin{array}{l}\text { On the plain; borders } \\
\text { part of the smallest } \\
\text { reservoir }(0.58 \mathrm{Km})\end{array}$ \\
\hline & 4 & $\begin{array}{l}\text { Predominantly grassland with } \\
\text { isolated shrubs; starts and ends } \\
\text { in the grassland-oak forest } \\
\text { ecotone, and crosses some } \\
\text { patches of low thorny shrubland }\end{array}$ & $\begin{array}{l}\text { On the plain; ends } \\
\text { at the border of two } \\
\text { ravines }(11 \mathrm{Km})\end{array}$ \\
\hline \multirow[t]{6}{*}{$\begin{array}{l}\text { Las Chinampas } \\
\text { ranch }\end{array}$} & 1 & $\begin{array}{l}\text { Predominantly open grassland; } \\
\text { crosses a small oak forest area }\end{array}$ & $\begin{array}{l}\text { On the plain; crosses a } \\
\text { small ravine }(1.2 \mathrm{Km})\end{array}$ \\
\hline & 2 & $\begin{array}{l}\text { Predominantly open grassland; it } \\
\text { ends in an area with shrubs and } \\
\text { oak forest }\end{array}$ & $\begin{array}{l}\text { On the plain; it ends } \\
\text { in a ravine }(0.6 \mathrm{Km})\end{array}$ \\
\hline & 3 & $\begin{array}{l}\text { Grassland with scattered oaks, } \\
\text { prickly-pear cacti, and yucca } \\
\text { trees; riparian areas with shrubs, } \\
\text { oak trees, and agaves }\end{array}$ & $\begin{array}{l}\text { Along the ravine with } \\
\text { two small bodies of } \\
\text { water }(0.73 \mathrm{Km})\end{array}$ \\
\hline & 4 & $\begin{array}{l}\text { Caespitose grassland with } \\
\text { scattered oak trees; ends in an } \\
\text { area with shrubs and oak forest }\end{array}$ & $\begin{array}{l}\text { On the plain; it ends } \\
\text { in a ravine }(1.1 \mathrm{Km})\end{array}$ \\
\hline & 5 & $\begin{array}{l}\text { Shrubland with agaves, prickly- } \\
\text { pear cacti, thorny bushes, and } \\
\text { isolated oaks }\end{array}$ & $\begin{array}{l}\text { Along a rocky ravine } \\
(0.57 \mathrm{Km})\end{array}$ \\
\hline & 6 & $\begin{array}{l}\text { Grassland with isolated oak trees } \\
\text { and yuccas }\end{array}$ & On the plain $(2.8 \mathrm{Km})$ \\
\hline
\end{tabular}

yuccas, as well as hillsides, ravines, and water bodies (Figure 1). A total of 10 routes of varying lengths were established across the study area, four in the ejido and six in the ranch (Table 1). Two routes in the ejido (1 and 4$)$ and two in the ranch ( 4 and 6 ) were traveled in vehicle at 4 to $6 \mathrm{~km} / \mathrm{h}$, while routs 2 and 3 of the ejido, as well as routs 1, 2, 3, and 5 of the ranch, were walked at a similar speed. Each route was traveled once per night for two non-consecutive nights each month, reversing the order and direction of the monitoring every night. In addition, four fixed recording stations were set in each site (fixed points - semi-active monitoring). The use of fixed points as supplements of routes contributes to better determine the spatial and temporal variation in the activity of bats (Stahlschmidt and Brühl 2012). At each fixed point, we recorded five minutes per night for two nonconsecutive nights per monitoring month. The monitoring along routs and at fixed points started at dusk with a duration of six to seven hours (from 19:00 to 20:00 to 2:00 to 3:00 $\mathrm{h}$, approximately). We used an EchoMeter three ultrasonic detector (Wildlife Acoustics, Inc., United States) for recording files in real-time and with the full spectrum. We used a sampling rate of $256 \mathrm{kHz}$, a trigger of $7 \mathrm{kHz}$, and $24 \mathrm{~dB}$; files had a maximum duration of one minute and were stored using a *.WAV format. The detector was equipped with a Garmin 18x GPS (Garmin, United States), making it possible to record the location where pulses of bat species were recorded.

This was supplemented by passive monitoring, placing a SongMeter Model SM2BAT automated ultrasonic detector equipped with an SMX-US microphone (Wildlife Acoustics, Inc., United States) attached to an antenna placed at each site (Figure 1). A sampling rate of $384 \mathrm{kHz}$ was used, Mono-L channel, which was stored as *.WAC format. These automated detectors were set to record continuously for 10 minutes each hour, from dusk to dawn, during 20 to 25 days/month (depending on the life of batteries). This method was used to identify peaks of activity throughout the year that may indicate migration periods of the various species. All the sounds were recorded in sound cards of high memory capacity (Secure Digital High Capacity-SDHC cards).

Analysis of sounds. The files stored by ultrasonic detectors in *.WAC format (native format) were converted to *.WAV format using the program WAC2WAV 3.3.0. (Wildlife Acoustics, Inc., United States). WAV files were loaded in the program BatSound v.4.1 (Pettersson Elektronic AB, Uppsala, Sweden) to visualize and analyze the sounds contained in recordings. We used different parameters of pulses (maximum frequency [FMAX], minimum frequency [FMIN], frequency of maximum energy [FME], duration [DUR], and interval between pulses [IPI]). FMIN and FMAX were calculated by subtracting $-10 \mathrm{~dB}$ from FME (Fenton 2004), while IPI was calculated from the end of a pulse to the beginning of the next, based on the oscillogram.

We estimated the activity index (IA) for each species in each route by adding up the number of 1-min blocks in which a species was detected as "present" (Miller 2001). We 
defined that a species was "present" when three or more consecutive pulses were clearly visualized in a block. Subsequently, for each route (including the fixed points), each month, and each species, we divided the total number of $1 \mathrm{~min}$ blocks with sound pulses recorded by the total number of minutes of recording. IA represents a gross estimate of the proportion of time that bats are active, and provides a standardized method to compare the relative abundance of a species through time in either multiple sampling sites or a single site (Miller 2001).

The shape and characteristics of ultrasonic pulses were analyzed with the program BatSound v.4.1, and then were compared with reference pulses obtained from fieldwork, the literature, and the acoustic libraries available. This comparison allowed us to identify the pulses to species level. For comparison purposes, these parameters were calculated in a similar way in the present study.

Environmental parameters. An automated monitoring station was set in the study area to determine the potential relationship of environmental conditions with the activity of the different species. The weather station (Vantage Pro2 Windows USB WeatherLink, Davis Instruments, United States) was set at approximately $3 \mathrm{~m}$ high on a ranch antenna. The weather station continuously recorded and stored the following data: wind speed and direction, ambient temperature and humidity, and precipitation. These variables were related only to the activity recorded in the passive monitoring station close to the weather station.

\section{Results}

Species richness through capture and acoustic monitoring. During the period between January and December 2012, only two bat individuals were captured in nets: one male of Myotis melanorhinus (Vespertilionidae) captured in March on the shore of the largest body of water (on the plain, rout 2 of the ejido), and one male of M. occultus (Vespertilionidae) captured in September on the shore of the body of water located in the ranch (near a small ravine, on rout 3 ). The acoustic analysis led to the identification of six species and a sound type assigned to M. occultus/M. californicus, belonging to three families: Mormoopidae, Molossidae, and Vespertilionidae (Table 2).

Activity related to landscape features and environmental parameters. The average (annual) activity index within the routes monitored for all species combined was 0.007 , indicating that bat vocalizations were recorded in less than $1 \%$ of the total recording time. The activity levels of the different species of insectivorous bats were concentrated in two seasons: the first, clearly defined in spring (April to May); the second, longer, from mid-summer to late fall (AugustDecember; Figure 2). The fixed detectors used for passive monitoring recorded activity only in March, April, and May, where $85 \%$ of the recorded sounds ( $n=28$ pulses) corresponded to $T$. brasiliensis, while $15 \%$ were produced by $M$. melanorhinus and $M$. velifer.
Table 2. Average values of the characteristics of search phase pulses recorded during the annual period in the Palo Alto region, Aguascalientes and Jalisco. FME: Frequency of Maximum Energy. FMIN: Minimum Frequency. FMAX: Maximum Frequency. DUR: Duration. IP: Interval between pulses. FMIN and FMAX were calculated by subtracting $-10 \mathrm{~dB}$ from FME (Fenton 2004). Values are the mean \pm standard deviation. NS: Number of sequences. Five pulses were measured in each sequence.

\begin{tabular}{lcccccc}
\hline \multicolumn{1}{c}{ Identification } & $\begin{array}{c}\text { FME } \\
(\mathbf{k H z})\end{array}$ & $\begin{array}{c}\text { FMIN } \\
(\mathbf{k H z})\end{array}$ & $\begin{array}{c}\text { FMAX } \\
(\mathbf{k H z})\end{array}$ & $\begin{array}{c}\text { DUR } \\
(\mathbf{m s})\end{array}$ & IP $(\mathbf{m s})$ & NS \\
\hline Mormoops megalophylla & $52.7 \pm 1.2$ & $51.2 \pm 2.0$ & $53.6 \pm 1.7$ & $9.4 \pm 1.6$ & $151.2 \pm 60.3$ & 4 \\
Nyctinomops macrotis & $14.6 \pm 2.1$ & $13.6 \pm 1.7$ & $19.9 \pm 1.3$ & $13.0 \pm 0.9$ & $332.1 \pm 22.1$ & 4 \\
Tadarida brasiliensis & $23.9 \pm 3.2$ & $23.1 \pm 1.4$ & $26.2 \pm 1.5$ & $9.4 \pm 2.0$ & $234.0 \pm 23.1$ & 48 \\
Eptesicus fuscus & $32.1 \pm 4.9$ & $29.0 \pm 1.8$ & $41.0 \pm 1.9$ & $6.4 \pm 2.2$ & $103.2 \pm 7.8$ & 10 \\
Myotis melanorhinus & $51.9 \pm 4.3$ & $50.7 \pm 2.1$ & $59.3 \pm 2.5$ & $6.0 \pm 3.3$ & $142.0 \pm 12.4$ & 26 \\
Myotis occultus/ & $44.8 \pm 0.3$ & $41.7 \pm 0.8$ & $54.2 \pm 1.3$ & $5.5 \pm 2.0$ & $88.8 \pm 9.5$ & 22 \\
californicus & & & & & & \\
Myotis velifer & $39.5 \pm 4.5$ & $37.6 \pm 3.3$ & $42.1 \pm 2.5$ & $3.6 \pm 1.3$ & $141.0 \pm 11.8$ & 5 \\
\hline
\end{tabular}

The results of the acoustic monitoring indicate that the highest activity of insectivorous bats concentrated in areas with bodies of water (rout 2 of the ejido and rout 3 from the ranch). In these routes, activity of bats was detected $16 \%$ of the total recorded time for the large pond of the ejido (rout 2), and $13 \%$ of the time for the ravine with water bodies in the ranch (rout 3; Figures 3A, 3B, 4A and 4B; Table 1). The concentration of activity in routes with water bodies was more evident for the vespertilionid species of the genus Myotis, while the activity of the molossid Tadarida brasiliensis was more homogeneous in all routes (Figures $3 \mathrm{~A}, 3 \mathrm{~B}, 4 \mathrm{~A}$ and $4 \mathrm{~B})$.

The temperature in study sites ranged from 1.7 up to 26.1 ${ }^{\circ} \mathrm{C}$ during the recording periods (19:00 to 3:00 h) throughout the year; the activity of bats was never recorded either below $6.8^{\circ} \mathrm{C}$ or above $20.3^{\circ} \mathrm{C}$. On the other hand, while wind speed in the area ranged between 0 and $38 \mathrm{~km} / \mathrm{h}$ throughout the year, the activity of bats occurred between 1.6 and $24.1 \mathrm{~km} / \mathrm{h}$. The species of the genus Myotis recorded activity between 9.8 and $16.7^{\circ} \mathrm{C}$, when wind speed ranged between 11.2 and $15.3 \mathrm{~km} / \mathrm{h}$. T. brasiliensis was active in the region when the temperature ranged between 6.8 and 20.3 ${ }^{\circ} \mathrm{C}$, at wind speeds ranging between 11.6 and $20.9 \mathrm{~km} / \mathrm{h}$.

\section{Discussion}

Species richness through capture and acoustic monitoring. The present study represents one of the first efforts to describe the activity patterns of insectivorous bats in arid landscapes dominated by open grassland and shrubland. The low capture rate of individuals in mist nets may reflect the low local abundance of bats, as reported in other temperate ecosystems dominated by pastures (i. e., Holloway and Barclay 2000). On the other hand, it is well known that many insectivorous species tend to be successful at evading mist nets (MacSwiney et al. 2009), which might have reduced the probability of capture. In addition, the study area, particularly the plain, is constantly exposed to low temperatures and high wind speeds (up to $38 \mathrm{~km} / \mathrm{h}$ or $10.5 \mathrm{~m} / \mathrm{s}$ ), which may inhibit the activity of both bats and their prey, which typically are more active in habitats with wind speeds below $6 \mathrm{~m} / \mathrm{s}$ or $21.6 \mathrm{~km} / \mathrm{h}$ (Arnett et al. 2011; Wellig et al. 2018). 
The present study recorded only seven species of insectivorous bats through acoustic detection techniques. However, other species of the genera Myotis (e. g., M. volans, M. auriculus) Lasiurus (L. blossevillii) and Aeorestes (A. cinereus) probably occur in the study area as well, because Palo Alto is located within their distribution range and the characteristics of the habitat are consistent with those used by most of these species (Álvarez-Castañeda et al. 2008).

It is also feasible that species of other guilds use this area as a transit or foraging sites. The species potentially present include the nectarivorous bats Choeronycteris mexicana, Leptonycteris nivalis, and L. yerbabuenae, which probably use the low areas of the plain that host a greater amount of flower resources (Valiente-Banuet et al. 1996). These species are hardly recorded in an acoustic sampling, since their echolocation sounds are short, multi-harmonic, of modulated frequency (FM), and produced at a very short distance from their target (González-Terrazas et al. 2016).

Spatial variation of insectivorous species. The artificial water bodies located in study sites were built by local ranchers to supply water for livestock. In northern México and other arid areas of the world, these artificial water reservoirs are key landscape elements for insectivorous bats, particularly in the dry season (López-González et al. 2015, 2016; Razgour et al. 2018). A similar pattern was observed in this study, with higher activity indices in the three bodies of water of the plain. In addition to the bodies of water, the recordings at fixed points indicated that open areas near the border of a zone of ravines ranked second in terms of the activity of insectivorous bats. These results are consistent with those reported for other open landscapes of North America, where natural water bodies and ravines are the sites showing the greatest activity (i. e., Holloway and Barclay 2000).

The species of the genus Myotis (family Vespertilionidae), characterized by its slow flight at a low height, are the species that showed the highest use of areas near water bodies in both the ejido and the ranch. The only two captures in the net ( $M$. melanorhinus and M. occultus) occurred around water bodies. The preference of Myotis spp. for

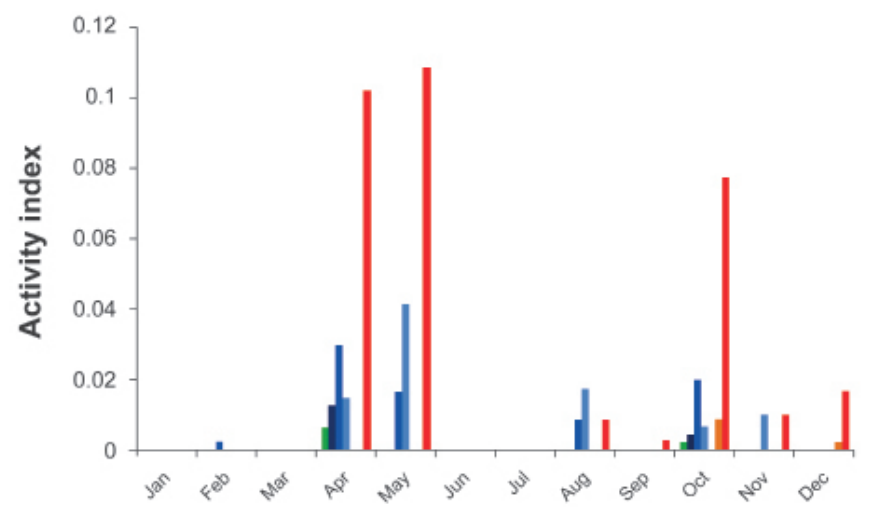

Figure 2. Levels of monthly activity of insectivorous bats recorded along routes in the study area. Green = Mormoops megalophylla, Dark blue = Eptesicus fuscus, Medium blue $=$ Myotis melanorhinus, Light blue $=$ Myotis occultus/Myotis californicus, Orange $=$ Nyctinomops macrotis, and Red = Tadarida brasiliensis. streams and water bodies can be due to several factors. In the first place, in arid areas, water bodies and the associated riparian vegetation display a greater abundance of insects (Hagen and Sabo 2012; Korine et al. 2016). In addition, the large amount of feces excreted by livestock visiting these sites for drinking water promotes a higher volume of organic matter that boosts the abundance of insects (López-González et al. 2015). Besides, these sites are attractive for bats to drink water (Adams and Thibault 2006). The species of Myotis were also active in ravines, areas that offer higher availability of shelters in trees and rocky walls ( $\mathrm{Hol}-$ loway and Barclay 2000; Everette et al. 2001). The species of the genus Myotis usually have short and broad wings that confer limited maneuverability in open areas, thus avoiding to fly in these areas (for example, grasslands) and instead use mostly linear elements (roads, rocky walls, rows of trees or shrubs, etc.) and streams as flight routes (Limpens and

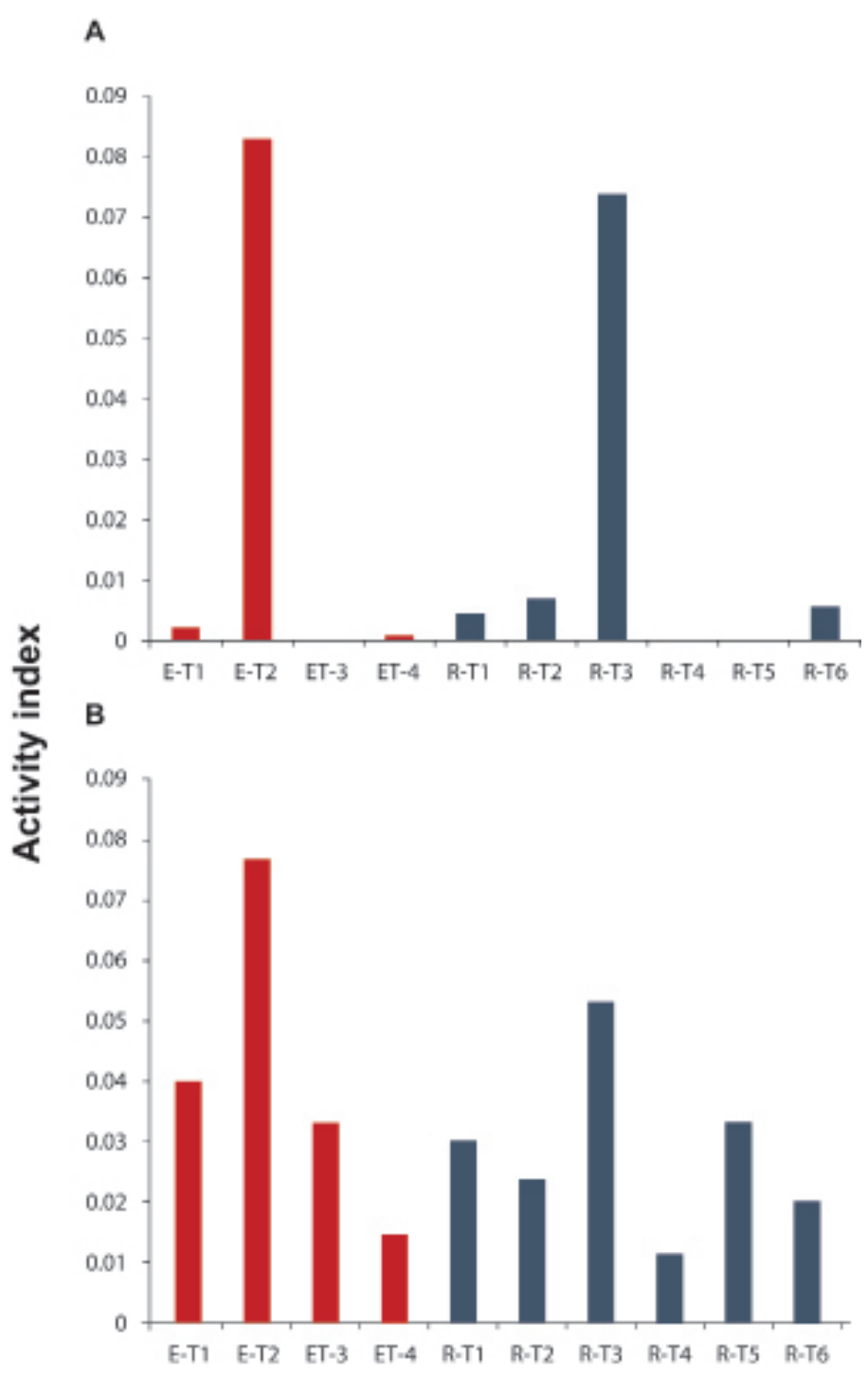

Transects

Figure 3. Activity levels of A: Myotis spp., and B: Tadarida brasiliensis in the routes of ejido (red) and ranch (blue), recorded during January-December 2012. $E=E j i d o, ~ R=$ Ranch, $\mathrm{T}=$ route or transect; the number indicates route number, either in the ejido or in the ranch. 
Kapteyn 1991). It has been speculated that these species may benefit from the linear elements because of the availability of topographic features for spatial orientation (they produce pulses of relatively high frequencies, resulting in a relatively low sonar range), and because these lower the risk of predation and provide protection against strong winds (Limpens and Kapteyn 1991).

The big free-tailed bat, Nyctinomops macrotis (family Molossidae), was active mainly in the largest body of water of the ejido and in ravine areas in both sites. It is highly likely that the low number of records of $N$. macrotis derives from its high flight (frequently close to $200 \mathrm{~m}$; Griffin and Thompson 1982), which would suggest that this species does not perceive the different components of the landscape at ground level (Ávila-Flores and Fenton 2005). At various points located in the study area but outside routes, audible vocalizations were occasionally attributable to this species (R. Ávila, pers. obs.), suggesting that this species uses the landscape in a relatively homogeneous manner. N. macrotis could be identified based on the recordings typical of the species that at the same time were related to sounds that are audible to humans, as observed in other regions inhabited by this species (Mora and Torres 2008). An accurate record of its audible vocalizations was not conducted because not all the field team members were trained to identify this species.

The molossid bat Tadarida brasiliensis, another highflight bat, was the most abundant species in the study area. Like N. macrotis, its high flight may make this species perceive the landscape in a more homogenous way (ÁvilaFlores and Fenton 2005), but it nonetheless used areas near bodies of water more frequently (Figure 3 ). As is the case of Myotis spp., these areas may provide a higher abundance of food, as well as protection against strong winds, given these were located in small ravines and gullies. The detection of an abundant number of pulses in fixed detectors and fixed evidence that this species is capable of using open habitats nearly as often as ravines and areas of woody vegetation.

The limited information obtained for Mormoops megalophylla, Eptesicus fuscus, and M.velifer preclude an adequate description of its habitat-use patterns. Mormoops megalophylla was detected in a body of water (ejido), in ravines (ranch), and open areas near ravines (Figure 4B). Apparently, this species uses the various habitats in the study area in a relatively similar way. For its part, E. fuscus, considered a generalist species that occurs commonly in arid habitats of central México (Kurta and Baker 1990), was recorded

A

B
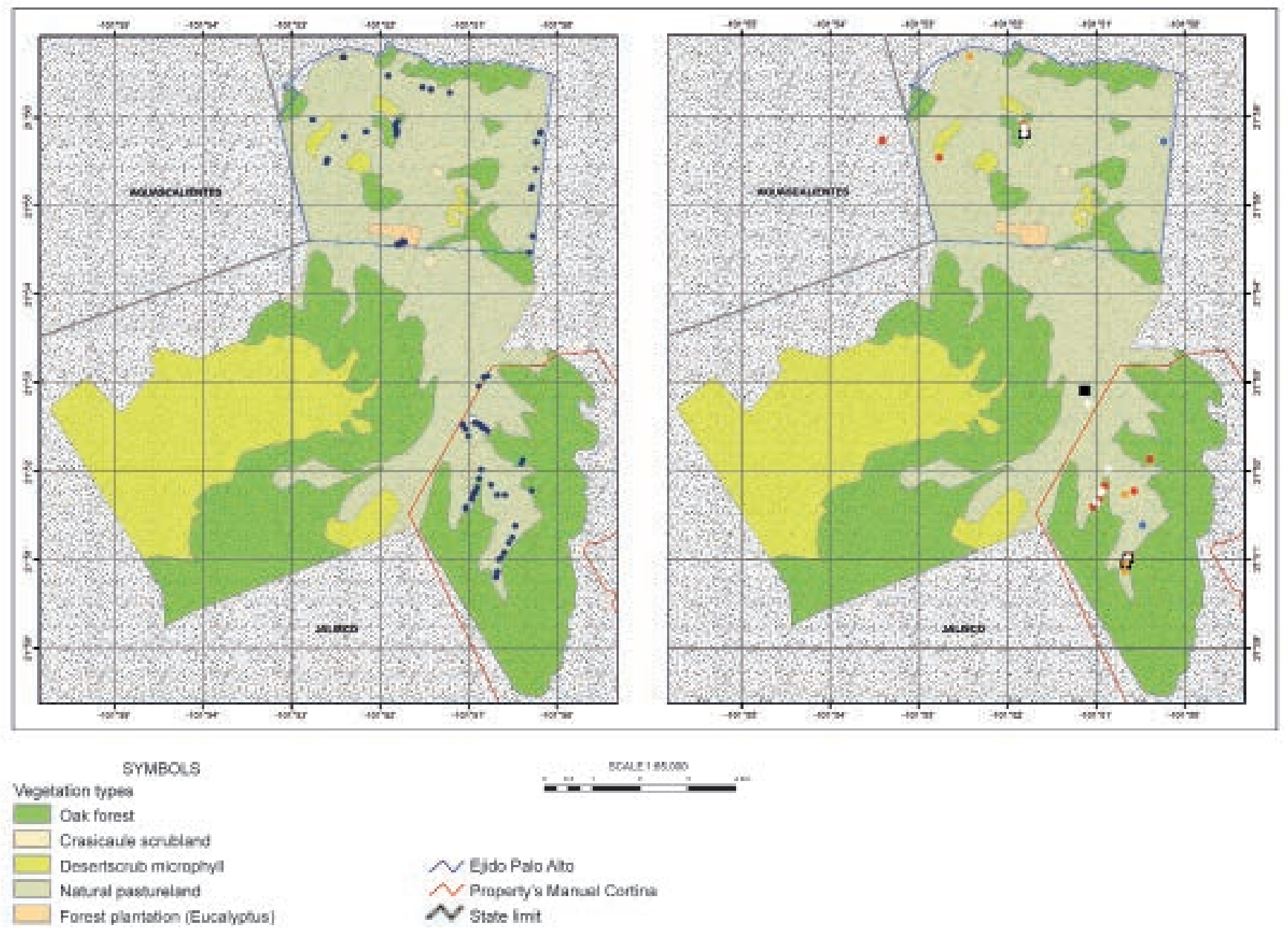

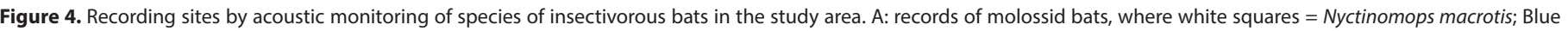

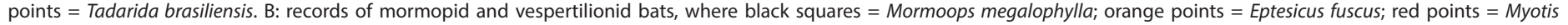
melanorhinus; white points $=$ Myotis occults; blue points = Myotis velifer 
mainly in ravines and adjacent open areas, while $M$. velifer was detected in a few occasions in the fixed detector placed in the ejido (i. e., in open areas) in April. Specimens of this species have been observed found in the study area resting on beams of the ex-hacienda Palo Alto in August (Álvarez-Castañeda et al. 2008), but the colony apparently consisted of a few individuals. The low abundance previously observed in the area could explain the few records of activity of this species in our study sites.

Temporal variation of insectivorous species. The species of the family Molossidae (N. macrotis and T. brasiliensis) were recorded in the Palo Alto region most of the year. Although N. macrotis was recorded a few times in the recordings, its presence was identified in several months of monitoring without the assistance of ultrasonic detectors. T. brasiliensis was detected in seven of the 12 monthly sampling events, with noticeable absences during the winter (January-March) and part of the summer (June-July), and with two peaks of activity in spring and autumn (Figure 2). In April, May, and October, the activity of this species was significantly relative to the other months, making it possible to record sounds during 8 to $10 \%$ of the recording time. The absence of records of T. brasiliensis in June and July is worth mentioning, since this period of time coincides with the onset of rains, the reproduction of the species, and a high abundance of insects (López-Vidal et al. 2008). These observations suggest that the increased activity of $T$. brasiliensis detected in spring may reflect the migratory movements of the species; this is difficult to confirm because its migratory routes in México are not known in detail yet.

The members of the family Vespertilionidae (E. fuscus, $M$. melanorhinus, $M$. occultus, and $M$. velifer) are active during a large part of the year in the Palo Alto region but virtually disappear between November and March. In México, it has been reported that these species usually make short altitudinal migrations to reach their hibernation sites (Villa 1967). The virtual absence during the coldest months seems to support this hypothesis, although it is unlikely that these populations hibernate in the Palo Alto region, considering that they tend to move toward higher sites in search of shelters that are sufficiently cold. The search for shelters and the interviews with local inhabitants did not provide evidence about hibernation shelters in the region. The individuals of the genus Myotis found in Palo Alto likely hibernate in the closest mountainous area, located some 80 to $90 \mathrm{~km}$ to the northeast (limits between Aguascalientes and Jalisco), reaching altitudes close to 3,000 masl. Until now, the few known hibernation shelters for $M$. velifer in México are occupied from September-October to February-March (e. g. Ávila-Flores and Medellín 2004; Ayala-Berdon and Solís-Cárdenas 2017).

Nocturnal activity and environmental parameters. The characteristics of our sampling design and the scarcity of data preclude a robust analysis of daily activity patterns of the different species of bats. However, the combination of the data for all sampling events allows us to get an over- all picture of the patterns of activity for the most common species in the area. In the case of the species of the genus Myotis, which tend to be more active shortly after dusk elsewhere (Hayes 1997), no peak of activity was detected between 20:00 and 3:00 h. In contrast, T. brasiliensis, a species that can travel across more than $50 \mathrm{~km}$ in a single night (Best et al. 2003), seems to display a peak of activity between 21:30 and 22:00 h. This pattern is similar to the one reported by Ávila-Flores et al. (2005) for T. brasiliensis in México City, with a peak of activity two hours after dusk.

The low activity of bats recorded in the Palo Alto region restrained the statistical analysis of the effect of the local climatic conditions. However, the available information documents that in the area no activity of bats occurs at temperatures either below $6.8^{\circ} \mathrm{C}$ or above $20.3^{\circ} \mathrm{C}$. In addition, the activity of bats occurred at wind speeds of 1.6 and 24.1 $\mathrm{km} / \mathrm{h}$. The data obtained is insufficient to know whether Myotis spp. and $\mathrm{T}$. brasiliensis are active at wind speeds above $24.1 \mathrm{~km} / \mathrm{h}$, but we can affirm that the peak activity of these species occurs when the wind flows below this speed. This is consistent with observations for North American insectivorous species that display peak activity when wind speed is below $6 \mathrm{~m} / \mathrm{s}$ or $21.6 \mathrm{~km} / \mathrm{h}$ (Arnett et al. 2011).

The present work represents one of the first efforts to determine the richness and activity of insectivorous bats in arid environments with desert shrubland. The low species richness and low activity levels recorded result from the environmental conditions that prevail in the plain, characterized by strong gusts of wind and low temperatures. In this area, similar to other arid areas, artificial water bodies ("presones") are an important element that promotes the activity and foraging of insectivorous bats (López-González et al. 2015). Maintaining these water elements is essential, particularly in the dry season, as our results show that it is in this season that insectivorous bats are most active, with the likely migratory movement of $T$. brasiliensis.

\section{Acknowledgments}

The authors wish to thank C. Alavez, P. Aguilar, Z. Vallado, V. Zamora, C. Tejeda, H. Gómez, M. Pérez, and J. Ramírez for their valuable assistance in fieldwork. We are grateful to $S$. Armenta and L. Ruíz Ruíz for their assistance in the elaboration of the figures. This research was conducted with the support of the Universidad Veracruzana and the Universidad Juárez Autónoma de Tabasco. We would like to thank two anonymous reviewers who improved the document. M. E. Sánchez-Salazar translated the manuscript into English.

\section{Literature cited}

Adams, R. A., and K. M. Thibault. 2006. Temporal resource partitioning by bats at water holes. Journal of Zoology, London 270:466-472.

Álvarez-Castañeda, S. T., E. Rios, A. Gutiérrez-Ramos, and L. Méndez. 2008. Lista comentada de mamíferos de Aguascalientes. Pp. 27-63 in Avances en el Estudio de los Mamíferos de México. Publicaciones Especiales, Vol. II 
(Lorenzo, C., E. Espinoza and J. Ortega eds.). Asociación Mexicana de Mastozoología, A. C. Ciudad de México, México. Arnett, E. B., M. M. P Huso, M. R. Schirmacher, and J. P. Hayes. 2011. Altering turbine speed reduces bat mortality at windenergy facilities Frontiers in Ecology and the Environment 9:209-214.

Ávila-Flores, R., ANd M. B. Fenton. 2005. Use of spatial features by foraging insectivorous bats in a large urban landscape. Journal of Mammalogy 86:1193-1204.

Ávila-Flores, R., And R. A. Medellín. 2004. Ecological, taxonomic, and physiological correlates of cave use by Mexican bats. Journal of Mammalogy 85:675-687.

Ayala-Berdón, J., And V. Solís-Cárdenas. 2017. New record and site characterization of a hibernating colony of Myotis velifer in a mountain ecosystem of central México. Therya 8:171-174.

Best T. L., K. N. Geluso, And L. K. Ammerman. 2003. Summer foraging range of Mexican free-tailed bats (Tadarida brasiliensis mexicana) from Carlsbad Cavern, New Mexico. The Southwestern Naturalist 48:590-596.

Challenger, A., And J. Soberón. 2008. Los ecosistemas terrestres. Pp. 87-90 in Capital natural de México, Vol. I (Soberón, J., G. Halffter, and J. Llorente-Bousquets, comp.). Comisión Nacional para el Conocimiento y Uso de la Biodiversidad. Ciudad de México, México.

Comisión Nacional para el Conocimiento y Uso de la Biodiversidad (conABIO). 2019. Matorrales. https://www.biodiversidad.gob. mx/ecosistemas/Matorral.html. Accessed 3 July 2019.

Elizalde-Arellano, C., J. C. López-Vidal, L. Hernández, J. W. Laundré, F. A. Cervantes, F. M. Morales-Mejía, M. RamírezVargas, L. F. Dávila-Galaviz, A. González-Romero, and M. Alonso-Spilsbury. 2014. Registro de presencia y actividades de algunos mamíferos en el Desierto Chihuahuense, México. Therya 5:793-816.

Everette, A. L., T. J. O’Shea, L. E. Ellison, L. A. Stone, and J. L. McCance. 2001. Bat use of a high-plains urban wildlife refuge. Wildlife Society Bulletin 29:967-973.

Fenton, M. B. 2004. Reporting: essential information and analysis. Pp. 133-140 in Bat echolocation research: tools, techniques and analysis (Brigham, R. M., E. K. V. Kalko, G. Jones, S. Parsons, and H. J. G. A. Limpens, eds.). Bat Conservation International. Austin, U.S.A.

Fleming, T. H., and J. N. Holland. 2018. Nectar Bat-Plant Interactions in North American Deserts. Hystryx-Italian Journal of Mammalogy 29:33-39.

García, E. 2004. Modificaciones al Sistema de Clasificación Climática de Köppen. Serie Libros Núm 6. Instituto de Geografía, Universidad Nacional Autónoma de México. Ciudad de México, México.

González-Terrazas, T. P., J. C. Koblitz, T. H. Fleming, R. A. Medellín, E. K. V. Kalko, H. U. Schnitzler, and M.Tschapka. 2016. How néctar-feeding bats localize their food: echolocation behavior of Leptonycteris yerbabuenae approaching cactus flowers. PLoS ONE 11:e0163492.

Griffin, D. R., AND D. Thompson. 1982. High altitude echolocation of insects by bats. Behavioral Ecology and Sociobiology 10:303-306

Hagen, E. M., ANd J. Sabo. 2012. Influence of river drying and insect availability on bat activity along the San Pedro River, Arizona (USA). Journal of Arid Environments 84:1-8.
Hayes, J. P. 1997. Temporal variation in activity of bats and the design of echolocation-monitoring studies. Journal of Mammalogy 78:514-524.

Herrera M., L. G. , ANd T. Lopez R. 2017. Columnar cacti as sources of energy and protein for frugivorous bats in a semiarid ecosystem. Biotropica 49:56-62.

Holloway, G. L., AND R. M. R. Barclay. 2000. Importance of prairie riparian zones to bats in southeastern Alberta. Ecosciencie 7:115-122.

Korine, C., R. Adams, D. Russo, M. Fisher-Phelps , and D. Jacobs. 2016. Bats and water: Anthropogenic alterations threaten global bat populations. Pp. 215-241 in Bats in the Anthropocene: Conservation of bats in a changing world (Voigt, C. C., and T. Kingston eds.). Springer International AG, e-book.

Kurta, A., ANd R. H. Baker. 1990. Eptesicus fuscus. Mammalian Species 356:1-10.

Limpens, H. J. G. A , AND K. KAPTEYN. 1991. Bats, their behaviour and linear landscape elements. Myotis 29:39-48.

López-González, C., A. Lozano, E. P. Gómez-Ruiz, and R. LópezWilchis. 2016. Activity of insectivorous bats is related to water availability in a highly modified Mexican temperate forest. Acta Chiropterologica 18:409-421.

López-González, C., E. P. Gómez-Ruiz, A. Lozano, and R. LópezWILCHIS. 2015. Activity of insectivorous bats associated with cattle ponds at La Michilía Biosphere Reserve, Durango, México: Implications for conservation. Acta Chiropterologica 17:117-129.

López-González, C., S. J. Presley, A. Lozado, R. S. Stevens, and C. L. Higgins. 2012. Metacommunity analysis of Mexican bats: environmentally mediated structure in an area of high geographic and environmental complexity. Journal of Biogeography 39:177-192.

López-Vidal, J. C., C. Elizalde Arellano, J. Arroyo-Cabrales, and R. A. Medellín. 2008. Observaciones sobre movimientos y comportamiento de Tadarida brasiliensis mexicana en la cueva El Salitre, Metztitlán, Hidalgo, México. Pp. 615-634 in Avances en el Estudio de los Mamíferos de México (Lorenzo, C., E. Espinoza, and J. Ortega, eds.). Asociación Mexicana de Mastozoología, A. C. Ciudad de México, México.

MacSwiney G., M. C., Bolívar-Cimé, B., F. M. Clarke, and P. A. RACEY. 2009. Insectivorous bat activity at cenotes in the Yucatán Peninsula. Acta Chiropterologica 11:139-147.

MacSwiney G., M. C., F. M. Clarke, And P. A. Racey. 2008. What you see is not what you get: the role of ultrasonic detectors at maximising inventory completeness in Neotropical bat assemblages. Journal of Applied Ecology 45:1364-1371.

Medellín R., H. T. Arita, and O. Sánchez. 2008. Identificación de los murciélagos de México. Clave de campo. Segunda Edición. Asociación Mexicana de Mastozoología, A.C. Ciudad de México, México.

Miller, B. W. 2001. A method for determining relative activity of free flying bats using a new activity index for acoustic monitoring. Acta Chiropterologica 3:93-105.

Mora, E. C, And L. Torres. 2008. Echolocation in the large molossid bats Eumops glaucinus and Nyctinomops macrotis. Zoological Science 25:6-13.

Stapp, P. 2010. Long-term studies of small mammal communities in arid and semiarid environments. Journal of Mammalogy 91:773-775. 
Razgour, O., M. Persey, U. Shamyr, and C. Korine. 2018. The role of climate, water and biotic interactions in shaping biodiversity patterns in arid environments across spatial scale. Diversity and Distributions 24:1440-1452.

Rojas-Martínez, A. E., and A. Valiente-Banuet. 1996. Análisis comparativo de la quiropterofauna del Valle de TehuacánCuicatlán, Puebla-Oaxaca. Acta Zoológica, Nueva Serie 67:1-23.

Rzedowskı, J. 2006. Vegetación de México. Comisión Nacional para el Conocimiento y Uso de la Biodiversidad. Ciudad de México, México.

Silva-Montellano, A., and L. E. Eguiarte. 2003. Geographic patterns in the reproductive ecology of Agave lechuguilla (Agavaceae) in the Chihuahuan desert. I. Floral characteristics, visitors, and fecundity. American Journal of Botany 90:377-387.

Stahlschmidt, P., ANd C. A. Bruhl. 2012. Bats as bioindicators the need of a standardized method for acoustic bat activity surveys. Methods in Ecology and Evolution 3:503-508.

Valiente-Banuet, A., C. Arizmendi, A. Rojas-Martínez, and L. Domínguez-Canseco. 1996. Ecological relationships between columnar cacti and nectar-feeding bats in México. Journal of Tropical Ecology 12:103-119.

Villa, R. B. 1967. Los murciélagos de México. Instituto de Biología. Universidad Nacional Autónoma de México. Ciudad de México, México.

Wellig, S. D., S. Nuslé́, D. Miltner, O. Kohle, O. Glaizot, V. Braunisch, M. K. Obrist, and R. Arlettaz. 2018. Mitigating the negative impacts of tall wind turbines on bats: Vertical activity profiles and relationships to wind speed. PLOS ONE 13:e0192493

Associated editor: Mariana Freitas Nery Submitted: July 11, 2019; Reviewed: August 22, 2019;

Accepted:September 18, 2019; Published on line:December 7, 2019. 
